\title{
Sepsis in Soft Tissue Limb Wounds in Soldiers Injured During the Falklands Campaign 1982
}

\author{
Major D S Jackson \\ $M B, C h B, F R C S, R A M C$
}

SUMMARY: The factors related to the development of sepsis in the soft tissue limb injuries sustained by soldiers during the Falklands Campaign have been assessed. Delay in surgery and delay in antibiotic administration are the most important factors, and where delay in surgery is inevitable, delay in antibiotic administration assumes an even greater importance.

\section{Introduction}

The principles of the management of battle casualties and the role of surgery in the treatment of missile injuries are well established ${ }^{1,3}$. Avoidance of septic complications with their associated increase in morbidity and mortality in the wounded has always been of paramount importance. This is achieved mainly by immediate antibiotic therapy, early debridement (within six hours) and delayed primary suture (DPS).

\section{Method}

Two hundred and thirty three soldiers were injured in the Falklands Campaign. Data were obtained from the field medical cards, case notes and Hostile Action Casualty System coding sheets, and the records of all soldiers who received soft tissue limb wounds were analysed. Burn injuries were excluded. There were 174 injuries to the limbs and of these 49 involved the soft tissues only, ie $28 \%$ did not damage bone. Twenty eight lower limb and 21 upper limb injuries were studied.

\section{Results}

The wounding agents covered the whole spectrum of weaponry (Table 1) and the range of tissue trauma varied from extensive, with tissue and skin loss and neurovascular injury, to minimal.

The time intervals from wounding to first surgery and wounding to antibiotic administration are given

Table I

Wounding Agents

\begin{tabular}{llll}
\hline $9 \mathrm{~mm}$ & 4 & SHELL & $5(2)$ \\
MINE & 5 & HV. UNSPEC & 2 \\
SHRAPNEL & $4(2)$ & HELO CRASH & 1 \\
$7.62 \mathrm{~mm}$ & $8(2)$ & SIDEWINDER & 1 \\
GRENADE & 4 & BOMB FRAGMENTS & 3 \\
MORTAR & $12(3)$ & TOTAL: & 49 \\
\hline
\end{tabular}

The figures in brackets indicate the number of cases in which sepsis developed. in Table II. Only 20 patients, 40\%, underwent $\vec{\omega}$ surgery before six hours had elapsed and nine patients, $18 \%$, were delayed over 15 hours. A higher number of patients however, $28(57 \%)$, received antibiotics before the six hour point.

Table III gives the intervals at which delayed primary suture was carried out and most operations took place between five and seven days after initiक surgery. Delay beyond this point was usually be? 음

Table II

Intervals: Wounding to Surgery and Antibiotics

\begin{tabular}{|c|c|c|c|c|c|c|}
\hline HOURS & $0-3$ & $4-6$ & $7-9$ & $10-11$ & $13-15$ & $>$ P \\
\hline $\begin{array}{l}\text { Wounding to } \\
\text { Surgery }\end{array}$ & 11 & 9 & 8 & 10 & 2 & \\
\hline Septic cases & 1 & 1 & 2 & 1 & 1 & \\
\hline $\begin{array}{l}\text { Wounding to } \\
\text { Antibiotics }\end{array}$ & 17 & 11 & 7 & 5 & 2 & \\
\hline Septic cases & 0 & 2 & 4 & 1 & 0 & \\
\hline
\end{tabular}

Table III

Intervals: Surgery to DPS

\begin{tabular}{lllll}
\hline Days & $0-4$ & $5-7$ & $8-10$ & $11-13$ \\
Number & $4(3)$ & $40(6)$ & $3(0)$ & $2(0)$ \\
\hline
\end{tabular}

The figures in brackets indicate the number of cases in which sepsis developed.

Table IV

Antibiotics used in limb wounds

MAGNAPEN

CRYSTAPEN

TRIPLOPEN

PENICILLIN ((UNSPEC)

TETRACYCLINE

METRONIDAZOLE

ERYTHROMYCIN 
cause of a dirty wound which required further dressings or further excision before safe closure. In this event skin grafts were used as a method of delayed closure. This technique was used for three legs and two arms.

All the wounded in this series were given antibiotic cover (Table IV) and these were mostly one of the penicillins. In only one case was a combination used, Triplopen and Metronidazole, the latter being employed to cover possible concomitant bowel injury'.

Of the 49 cases reviewed, three patients had septic wounds at delayed primary suture, ie frank pus in the wound, an incidence of only $6 \%$ : but subsequent infection after delayed primary suture developed in a further six cases making a total of nine or $18 \%$. Erythematous or moist wounds, very minor degrees of infection, have been excluded, as have those wounds which had primary closure delayed because of separating sloughs and were not overtly clinically infected.

Examination of the time intervals between injury and first surgery in those casualties who developed sepsis (Table II) reveals that seven of the nine cases occurred when wound excision was delayed beyond six hours. Twenty-one of the 49 casualties were given antibiotics after six hours.

Septic wounds also resulted in seven of the nine cases in whom the giving of antibiotics was delayed beyond six hours. Twenty-one of the 49 casualties were given antibiotics after six hours.

Unfortunately there was insufficient time to prepare a fifth table showing the delay to surgery in those cases in which antibiotics were administered within three and six hours respectively.

Table I also gives details of the wounding agents in the septic cases and does not suggest any link between the nature of the agent and the development of infection as the cases are evenly distributed.

Delayed primary suture was used as a method of closure in all casualties in this series and Table III illustrates the intervals between initial surgery and closure in the septic cases. It is striking that no infection occurred after DPS when that interval was greater than seven days.

\section{Discussion}

The prevailing conditions in the Campaign led to erratic and often very delayed casualty evacuation, particularly as most of the battles commenced at night, and helicopter transport was in short supply².

Current military surgical teaching dictates that all operations should be performed within six hours of injury to reduce infective complications ${ }^{1}$. Twenty nine of the 49 casualties were treated after six hours had elapsed and this can readily be explained by the nature of the terrain and the consequent $\Omega$ evacuation difficulties, coupled with the application 0 of the triage system relegating these injuries to acs lower priority when force of circumstances dictated it ${ }^{1,3}$. The infection rate in this group approached $25 \%$ and this high infection rate can be relatedo to delay in the primary wound excision.

There were no septic complications when anti $-\frac{\bar{m}}{\frac{D}{\sigma}}$ biotics were administered within three hours of $\stackrel{\mathbb{Q}}{\mathscr{Q}}$ wounding and this confirms recent experimental work showing that early antibiotic therapy (benzylpenicillin) totally inhibits the usual growth of ${ }^{\circ}$ bacteria in missile wounds when excision is delayed $\vec{\omega}$ for 12 hours 4 . It would appear that the antibiotic. prevents the growth of the initial sparse mixed flora of contaminants derived from clothes and skin which, were they allowed to thrive, would have? prevented the recovery of reversibly damaged tissue and led to super-infection with more patho- ${ }^{\circ}$ genic organisms. In addition, the recovery of tissie damaged on the periphery of the wound leads to more limited primary excision. In another experi-은 mental study by the same authors with no ant biotic therapy, the conclusion is reached that inferstion can be overcome by wound excision within six? hours but would be out of control by 12 hours 5 .

Owen-Smith and Matheson demonstrated thrit benzylpenicillin totally protected clostridial-contan nated sheep thigh wounds from gas gangrene pro vided that antibiotics were given within nine hoū̄s of wounding ${ }^{6}$. No cases of gas gangrene were encountered in the limb injuries reviewed, but the infection rate in this series in that group of wounded who received antibiotics beyond six hours after $\cong$ injury was $33 \%$.

The extent of initial wound excision is an un- 3 known quantity in this series, the patients having been operated upon by several different surgeons of varying experience in the management of these 3 types of wounds ${ }^{2}$. However, inadequate or insufficient wound excision will substantially contribute to the development of sepsis if at delayed primary $\vec{D}$ suture devitalised tissue is not recognized and closure is undertaken. It should be appreciated that the second operation in the treatment of a battle 3 . wound provides an opportunity to inspect it and re-excise it where necessary and not just to close it. 3 Indeed, altering the emphasis of the second operation from closure to inspection may permit a more conservative initial excision. In this series six cases of sepsis developed after delayed primary suture suggesting that the wounds were closed inappropri- $\sigma$ ately. Five cases were closed well beyond the seven $N$ day point because of wounds which were of doubtful N cleanliness. None became septic. 


\section{Acknowledgements}

I would like to thank Col R Scott L/RAMC, Professor of Military Surgery, for his help in the preparation of this paper and Mrs. Vera Crawford for the typing of the manuscript.

\section{REFERENCES}

1 Field Surgical Pocket Book. Kirby N G, Blackburn G. London HMSO 1981.

2 JaCKSON D S, et al. Falklands War: Army Field Surgical Experience. Ann $R$ Coll Surg 1983; 65: 281-285.

3 OWEn-Smith, M S. High Velocity Missile Injuries in Hadfield J. Hobsley M. Ed Current Surgical Practice. Vol 2 London. Edward Arnold. 1978; 204-229.
4 DAhlgren B, et al. Local Effects of Antibacterial Therapy (Benzylpenicillin) on Missile Wound Infec- $\varrho$ tion Rate and Tissue Devitalisation when Debride-? ment is Delayed for Twelve Hours. Acta Chir윽 Scand Suppl 1982; 508: 271-279.

5 Dahlgren B, et al. Findings in the First Twelve $\Rightarrow$ Hours Following Experimental Missile Trauma.心 Acta Chir Scand. 1981; 147: 513-518.

6 OWen-Smith M S, Matheson J M. Successful Prophylaxis of Gas Gangrene of the High Velocity Missile Wound in Sheep. Br $J$ Surg 1968; 55; I: 36-39.

\section{Reports of Meetings}

\section{Association of Service Physicians}

The fifth Annual Meeting of the Association of Service Physicians was held at the Royal Army Medical College Millbank, on 17 February 1984. Forty two members and guests attended, and the Chairmen were Group Captain D H Hull, RAF Consultant Adviser in Medicine, and Surgeon Captain $\mathbf{J} \mathbf{M}$ Beeley, RN Consultant, RN Consultant Adviser in Medicine.

Lt Col D Jolliffe opened the meeting with an account of Belizian Cutaneous Leishmaniasis as seen in British Servicemen, and its treatment with Pentostam, which in standard dosage appears highly effective and free from significant side effects. Major A Henderson then described his very thorough and fascinating work on Japanese B Encephalitis in Nepal, as published earlier in this Journal' ${ }^{1}$.

In the third presentation, Col $\mathbf{M}$ Templer gave details of an outbreak of Trichinella Spiralis infestation which occurred in Gurkha soldiers in Hong Kong in 1981. Trichiniasis was previously unknown in the colony,, but following this outbreak several cases have subsequently been diagnosed in Chinese residents by civilian physicians.

After a short break, the second session opened with a paper by Surg $\mathrm{Lt} \mathrm{Cdr} \mathbf{M}$ Edmondson comparingo the feature of Sarcoidosis seen in caucasian, black음 and asian patients attending two hospitals in the Bal@ ham area of South London since 1970 . Finally Group $\overrightarrow{\vec{b}}$ Captain Hull gave details of a study into the effects of 3 cigarette smoking patients being treated for duod? nal ulcer with Cimetidine. Although the majority of patients healed with treatment regardless of theirs smoking habits, there was a much higher relapse rate six months after stopping treatment in those who con tinued to smoke. It was also of interest that the majority of patients found to have relapsed (by endoscopy) remained totally asymptomatic.

(Submited by Lt Col T B N Oldreys (Secretary to the Association

\section{REFERENCES}

1 Henderson A. Encephalitis in Nepal: The Visitationg of the Goddess of the Forest. J R Army Med Corps 1983; 129: 156-162. 